\title{
Pemanfaatan Media Kit Oleh Guru Dalam Pembelajaran IPA Untuk Meningkatkan Hasil Belajar Siswa di SMP Negeri 4 Kota Singkawang
}

\author{
Nirwana Ismail \\ SMP Negeri 04 Singkawang, Jl. Bambang Ismoyo No.47, Singkawang, Kalimantan Barat \\ E-mail: nirwanaismail@gmail.com
}

\begin{abstract}
Abstrak. Penelitian ini bertujuan untuk meningkatkan hasil belajar yang dicapai siswa dengan pemanfaatan media. Jenis penelitian dalam penelitian ini adalah kualitatif. Dan bentuk penelitiannya adalah deskriftif. Alat pengumpul data yang digunakan yaitu tes, wawancara, dan observasi. Dari pemanfaatan media Kit yang digunakan terbukti dapat meningkatkan kemampuan penguasaan materi pembelajaran serta meningkatkan kemampuan kinerja ilmiah siswa terutama dalam melakukan percobaan, melakukan pengamatan, pengambilan keputusan dan melaporkan hasil percobaan. Sesuai hasil observasi, wawancara dengan guru dan siswa diperoleh data bahwa dalam pelaksanaan pemanfaatan media Kit dalam pembelajaran, guru menunjukkan kemampuannya mengoperasikan media Kit, melibatkan siswa, memberikan bimbingan kepada siswa dan memperhatikan keselamatan dalam pemanfaatan media Kit selama pembelajaran.
\end{abstract}

Kata Kunci: pemanfaatan, media Kit, pembelajaran IPA, hasil belajar

\section{PENDAHULUAN}

Peningkatan kualitas sumber daya manusia menjadi penting untuk mengantisipasi perkembangan ilmu pengetahuan dan teknologi yang semakin pesat di berbagai bidang kehidupan dan persaingan global dewasa ini. Sumber daya manusia yang berkualitas diharapkan mampu memanfaatkan peluang untuk mencapai kehidupan yang lebih baik. Sumber daya manusia yang berkualitas dapat diwujudkan melalui penyelenggaraan pendidikan yang berkualitas, diantaranya pendidikan sekolah. Dalam UU No. 2 Tahun 2003 dinyatakan bahwa tujuan pendidikan nasional untuk mengembangkan potensi siswa agar menjadi manusia Indonesia yang beriman dan bertaqwa terhadap Tuhan Yang Maha Esa, berakhlak mulia, sehat, berilmu, cakap, kreatif, mandiri, dan menjadi warganegara yang demokratis serta bertanggungjawab [1].

Pengembangan potensi siswa melalui pendidikan sekolah dilaksanakan mulai dari jenjang pendidikan dasar untuk meningkatkan kualitas manusia Indonesia seutuhnya agar memiliki daya saing dalam menghadapi tantangan global. Potensi siswa dikembangkan melalui penyelenggaraan pembelajaran pada sejumlah mata pelajaran yang mengarah pada olahhati, olahpikir, olahrasa dan olahraga. Salah satu mata pelajaran dalam pendidikan sekolah yang mengemban misi pengembangan potensi siswa adalah mata pelajaran IPA.

IPA merupakan salah satu mata pelajaran yang terdapat dalam kurikulum Sekolah Menengah Pertama untuk membekali siswa dengan pengetahuan, sikap dan keterampilan mengarah pada tujuan pendidikan nasional. Pendidikan IPA diharapkan dapat menjadi wahana bagi siswa untuk mempelajari diri sendiri dan alam sekitar, serta prospek pengembangan lebih lanjut dalam menerapkannya di dalam kehidupan sehari-hari. Dengan kata lain, pembelajaran IPA menghendaki penguasaan kompetensi yang berkaitan dengan pemahaman yang lebih mendalam tentang alam sekitar dan diterapkan dalam memecahkan permasalahan kehidupan sehari-hari. Karena itu, pembelajaran IPA hendaknya dilaksanakan sesuai dengan permasalahan yang dihadapi siswa dalam kehidupan sehari-hari.

Salah satu aspek yang perlu mendapat perhatian agar pembelajaran IPA dapat memberikan pengalaman belajar sesuai kehidupan sehari-hari siswa adalah pemilihan media pembelajaran. Belajar merupakan suatu proses perolehan atau 
perubahan terhadap pengertian-pengertian mendalam (insight), pandangan-pandangan (outlook), harapan-harapan atau pola-pola berpikir. Proses perolehan atau perubahan terhadap pengertian yang mendalam (insight) membutuhkan alat pendidikan ataupun media pembelajaran Selanjutnya, media pembelajaran dapat memberikan kemungkinan bagi siswa untuk menguasai kompetensi sesuai tujuan yang diharapkan [2]. Selain itu, media pembelajaran dapat pula meningkatkan perhatian siswa sehingga pembelajaran lebih menarik. Sejalan dengan pendapat Hamalik "pemakaian media pembelajaran dalam proses belajar mengajar dapat membangkitkan keinginan dan minat yang baru, membangkitkan motivasi dan rangsangan kegiatan pembelajaran dan bahkan membawa pengaruhpengaruh psikhologis bagi siswa" [3].

Pembelajaran IPA di sekolah disinyalir masih lemah dan belum kondusif dalam hal mewujudkan aktivitas siswa. Bundu mengatakan: "kelemahan pembelajaran IPA diakibatkan masih banyak guru yang menekankan pembelajaran pada faktor ingatan, sangat kurang pelaksanaan praktikum, dan fokus penyajian dengan ceramah yang menyebabkan penyajian sangat terbatas, tidak lebih dari mendengar dan menyalin" [4]. Tujuan pembelajaran IPA belum sepenuhnya tercapai, dapat dilihat dari rendahnya perolehan hasil belajar siswa dan keterampilan berpikir kritis dan ilmiah terhadap permasalahan lingkungan sekitar. Kendala lain yang dihadapi adalah pembelajaran masih dititik beratkan pada ketuntasan materi dari pada penguasaan kompetensi siswa. Pembelajaran yang berorientasi pada keterampilan proses, produk IPA dan sikap ilmiah belum optimal. Kondisi ini menghendaki kejelian guru untuk mencari alternatif pemecahan permasalahan pembelajaran IPA diantaranya melalui pemanfaatan media pembelajaran yang tepat.

Pembelajaran dengan media yang tepat dapat meningkatkan motivasi belajar siswa, mendorong aktivitas belajar, mengembangkan kemampuan berpikir kritis, serta menumbuhkan kepercayaan diri siswa. Melalui media diharapkan siswa dapat memberikan respon terhadap bahan pembelajaran yang menjadi topik pembahasan. Pemanfaatan media dapat pula mewujudkan pembelajaran lebih

efektif dan efisien, memungkinkan pembelajaran lebih menarik sehingga dapat meningkatkan minat siswa terhadap pembelajaran [5]. Kondisi demikian juga dibutuhkan dalam upaya mewujudkan pembelajaran IPA yang efektif dan efisien.

Kegiatan pembelajaran IPA dengan menggunakan media yang tepat akan memungkinkan siswa mencapai tujuan pembelajaran secara optimal. Pemanfaatan media yang dikemas dengan baik diarahkan untuk menumbuhkan aktivitas siswa sehingga terwujud interaksi antar siswa dengan materi pembelajaran, guru dan siswa lainnya. Respon yang diberikan siswa terhadap tugas-tugas pembelajaran yang diberikan melalui media pembelajaran menunjukkan tingkat aktivitas belajar siswa. Semakin tinggi aktivitas belajar yang dimiliki akan menentukan tingkat penguasaan pengalaman belajar yang diperoleh siswa dalam mendukung pencapaian kompetensi yang diharapkan. Pengalaman belajar memungkinkan diperoleh siswa melalui interaksi dengan bahan ajar, menyelesaikan tugas-tugas pembelajaran, memecahkan masalah sesuai topik pembelajaran. Penyelesaian tugas-tugas pembelajaran membutuhkan kemampuan berpikir kritis siswa untuk mengidentifikasi masalah yang harus dipecahkan dan menentukan alternatif pemecahan masalah. Dengan demikian, pemanfaatan media dapat meningkatkan aktivitas belajar, menumbuhkan interaksi yang optimal terhadap bahan pembelajaran, menyelesaikan tugas dengan kemampuan sendiri sehingga memungkinkan pencapaian hasil belajar secara optimal.

Hasil belajar merupakan gambaran proses pembelajaran yang dilaksanakan melalui keterlibatan seluruh komponen secara optimal mengarah pada tujuan. Pembelajaran IPA melalui pendekatan keterampilan proses mendorong terbentuknya sikap ilmiah diantaranya kemampuan mengamati, melakukan percobaan, memprediksi, melakukan penelitian, dan memecahkan masalah. Pengembangan keterampilan proses diharapkan mampu mewujudkan pembelajaran IPA yang aktif, efektif dan menyenangkan, serta memberikan peluang pencapaian hasil belajar yang optimal. Media Kit menjadi salah satu alternatif untuk menciptakan pembelajaran IPA yang efektif dan 


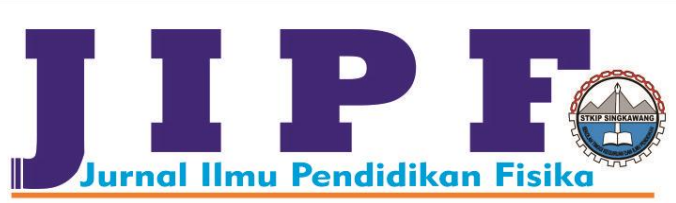

menyenangkan sehingga mampu memberikan pengalaman belajar yang optimal kepada siswa.

Kenyataannya, berdasarkan hasil observasi pembelajaran IPA di salah satu SMP di Kota Singkawang diperoleh informasi bahwa sebagian besar pembelajaran IPA khususnya pada materi kajian fisika masih menggunakan pembelajaran konvensional dengan metode ceramah, lebih menitikberatkan penguasaan materi dan kurang memberikan pengalaman keterampilan praktik. Wawancara yang dilakukan dengan salah satu guru diperoleh informasi bahwa aktivitas dan motivasi siswa di SMP tersebut masih rendah, dan siswa cenderung kurang bersemangat selama mengikuti pembelajaran di kelas. Akibatnya, penguasaan konsep IPA yang dicapai siswa masih tergolong rendah, terbukti dari pencapaian hasil ujian IPA dalam dua tahun terakhir di SMP tersebut hanya mencapai rata-rata 5,08 pada tahun pelajaran 2008/2009 dan 5,40 pada tahun pelajaran 2009/2010.

Berdasarkan pertimbangan di atas, upaya untuk mengungkap secara objektif tentang pemanfaatan media Kit yang dilaksanakan guru dalam pembelajaran IPA dirasakan cukup rasional untuk dilakukan. Pemanfaatan media Kit dalam pembelajaran IPA di SMP Negeri 4 Kota Singkawang perlu diperoleh informasinya melalui penelitian.

\section{METODE}

Permasalahan yang menjadi fokus dalam penelitian ini adalah pemanfaatan media Kit oleh guru dalam pembelajaran IPA, karena itu perlu ditentukan lokasi penelitian yang dapat memberikan informasi yang dibutuhkan. Berdasarkan pertimbangan di atas, maka peneliti menentukan SMP Negeri 4 Kota Singkawang sebagai tempat penelitian. Penelitian dilaksanakan di semua tingkat kelas pada semester genap tahun pembelajaran 2010/2011. Waktu penelitian dimulai bulan Maret 2011 sampai dengan Juni 2011.

Fokus penelitian adalah pemanfaatan media Kit oleh guru dalam pembelajaran IPA di SMP Negeri 4 Kota Singkawang. Subjek penelitian adalah situasi pembelajaran IPA. Sumber data penelitian meliputi: pembelajaran IPA dengan pemanfaatan media Kit, Guru mata pelajaran IPA serta siswa
Jurnal Ilmu Pendidikan Fisika

Volum 1 Nomor 1 Maret 2016. Halaman 16-22 p-ISSN: 2477-5959 e-ISSN: 2477-8451

Kelas VII,VIII,IX SMP Negeri 4 Kota Singkawang tahun pelajaran 2010/2011.

Metode penelitian yang digunakan adalah penelitian deskriptif kualitatif. Metode deskriptif melukiskan variabel atau kondisi apa yang ada dalam suatu situasi [6]. Sugiyono mengatakan metode kualitatif adalah metode penelitian untuk meneliti pada kondisi objek yang alamiah, peneliti sebagai instrumen kunci dan menggunakan teknik pengumpulan data secara triangulasi [7].

Dengan demikian penelitian deskriptif kualitatif adalah penelitian yang menggambarkan suatu objek apa adanya secara alamiah dengan peneliti sebagai instrumen kunci. Situasi yang digambarkan dalam penelitian ini adalah pemanfaatan media Kit oleh guru dalam pembelajaran IPA di SMP Negeri 4 Kota Singkawang.

Situasi sosial yang diamati dalam penelitian ini adalah pemanfaatan media Kit dalam pembelajaran IPA, maka yang menjadi subjek penelitian adalah guru mata pelajaran IPA di SMP Negeri 4 Kota Singkawang yang berjumlah enam orang dan siswa SMP Negeri 4 Kota Singkawang tahun pelajaran 2010/2011 berjumlah 463 orang.

Sampel penelitian akan dipilih sebagian yaitu informan-informan terpilih yang kaya dengan kasus untuk studi yang bersifat mendalam sebagai sampel purposif [8]. Sampel penelitian akan dipilih sebagian sebagai sampel purposif yaitu penentuan sampel dengan pertimbangan tertentu yaitu keterbatasan kemampuan peneliti untuk meneliti seluruh subjek penelitian [7]. Informan terpilih yang dijadikan sumber data penelitian dengan pertimbangan kualifikasi akademik, pengalaman kerja bagi guru mata pelajaran IPA serta hasil belajar yang diperoleh siswa dalam pembelajaran IPA bagi siswa. Dengan demikian informan terpilih pada penelitian ini adalah guru IPA di kelas VII,VIII dan IX SMP Negeri 4 Kota Singkawang dan siswa kelas VII,VIII, dan IX yang terpilih.

Sasaran penelitian adalah pemanfaatan media Kit oleh guru dalam pembelajaran IPA di SMP Negeri 4 Kota Singkawang. Aspek-aspek yang menjadi fokus pengamatan dalam pemanfaatan media Kit dalam pembelajaran IPA meliputi: pemilihan media Kit sesuai dengan materi pembahasan pembelajaran IPA, kegiatan-kegiatan yang dilaksanakan dalam persiapan pemanfaatan media Kit, kemampuan guru 


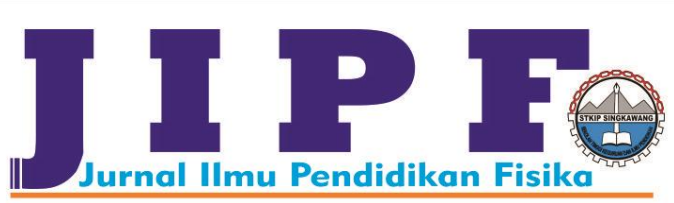

dan siswa dalam menggunakan media Kit dalam pembelajaran IPA, serta faktor-faktor yang mendukung dan menghambat dalam pemanfaatan media Kit dalam pembelajaran IPA.

Aspek-aspek yang menjadi fokus perhatian penelitian merupakan fenomena yang tampak pada pemanfaatan media Kit oleh guru baik sebelum pelaksanaan pembelajaran seperti proses pemilihan dan persiapan penggunaan media Kit maupun kegiatan dalam proses pembelajaran IPA dengan penggunaan media Kit seperti: langkah-langkah pemanfaatan media Kit, kemampuan guru dan siswa menggunakan media Kit, suasana pembelajaran yang terjadi, dan hal-hal yang dialami guru dalam pemanfaatan media Kit.

Prosedur pengumpulan data dalam penelitian ini berkaitan dengan teknik pengumpulan data yang digunakan, alat pengumpul/perekam data, serta validitas dan reliabelitas instrumen penelitian.

Teknik pengumpulan data yang digunakan dalam penelitian ini adalah teknik observasi langsung, komunikasi langsung dan komunikasi tidak langsung. Instrumen yang digunakan adalah sebagai berikut :

a. Observasi digunakan untuk mengamati pelaksanaan pemanfaatan media Kit dalam pembelajaran IPA yaitu: (1) tahapan pelaksanaan pemanfaatan media Kit dalam pembelajaran IPA (2) Aktivitas guru dan siswa selama pemanfaatan media Kit dalam pembelajaran IPA. Alat yang digunakan pedoman observasi, handicam, dan catatan-catatan hasil observasi.

b. Wawancara digunakan untuk menggali data dalam bentuk ucapan, tindakan, dan situasi lapangan dari sasaran klien yang refresentatif. Wawancara dilakukan terhadap guru mata pelajaran IPA dan beberapa siswa Kelas VII,VIII,dasn IX di SMP Negeri 4 Kota Singkawang. Alat yang digunakan panduan wawancara dan catatan hasil wawancara.

c. Perekam digunakan untuk merekam data-data penelitian berupa kegiatan seperti: proses pembelajaran IPA, penggunaan media Kit dalam pembelajaran IPA, dan pelaksanaan wawancara dengan sumber data/informan. Alat yang digunakan adalah kamera digital, handicam.

validitas dan Reliabelitas instrumen pada penelitian yang dilakukan sebagai berikut :

a. Validitas instrumen dilakukan dengan konsultasi instrumen kepada ahli dan analisia hasil isian instrumen oleh subjek penelitian sehingga instrumen dapat memenuhi persyaratan untuk memperoleh informasi sesuai kebutuhan penelitian.

b. Reliabelitas instrumen dilakukan secara eksternal dengan metode paralel (equivalent) melalui: kesamaan persepsi yang diberikan oleh subjek penelitian.

Analisis data dalam penelitian kualitatif dilakukan selama proses pengumpulan data berlangsung dan sesudah proses pengumpulan data. Analisis data yang digunakan dalam penelitian ini menggunakan model Milles Huberman dengan langkah-langkah sebagai berikut: (a) data reduction (reduksi data), (b) data display (penyajian data), dan (c) conclucion drawing/verification (penarikan kesimpulan dan verifikasi) [9].

a. Reduksi Data

Tahapan ini merupakan proses pemilihan, pemusatan perhatian pada penyederhanaan, pengabstrakan, dan transformasi data kasar yang muncul dari catatan-catatan tertulis di lapangan selam proses penelitian berlangsung. Data yang diperoleh dilakukan kemudian dibuat ringkasan, mengkode, memilah-milah mana yang penting dan mana yang dibuang, menelurusi tema,serta membuat memo.

b. Penyajian Data

Setelah reduksi data kemudian dilanjutkan dengan penyajian data. Data yang diperoleh melalui reduksi data kemudian disederhanakan dan disajikan sesuai pengelompokan yang dilakukan. Penyajian data dalam penelitian ini dilakukan dalam bentuk naratif, kemudian disajikan dalam bentuk bagan, tabel, dan matrik dan jaringan agar lebih mudah dalam menarik kesimpulan.

c. Penarikan Kesimpulan/Verifikasi

Berdasarkan penyajian data kemudian dilakukan penarikan kesimpulan berdasarkan data-data dan bukti-bukti yang diperoleh melalui instrumen penelitian. Kesimpulan dibuat dalam bentuk deskripsi naratif sebagai temuan penelitian yang kemudian dibandingkan dengan permasalahan penelitian.

Pemeriksanaan keabsahan data atau triangulasi dilakukan untuk mengecek data dari berbagai 


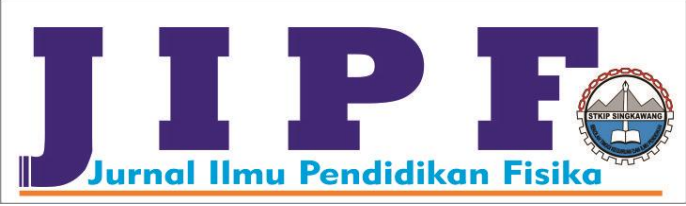

sumber dengan berbagai cara dan berbagai waktu [7]. (Triangulasi yang digunakan dalam penelitian ini adalah:

1. Triangulasi sumber yaitu menguji keabsahan data yang diperoleh dari berbagai sumber. Dalam penelitian ini, triangulasi sumber dilakukan terhadap data yang diperoleh dari guru mata pelajaran IPA dan siswa yang dipilih sebagai sumber data.

2. Triangulasi teknik yaitu pengujian keabsahan data yang diberoleh dari berbagai teknik pengumpulan data. Dalam penelitian ini triangulasi teknik dilakukan terhadap data yang diperoleh melalui observasi, wawancara, dan dokumentasi.

\section{HASIL DAN PEMBAHASAN}

Hasil belajar diperoleh dari tes pada akhir kegiatan pembelajaran dan penilaian kinerja ketika pelaksanaan pemanfaatan media Kit dalam pembelajaran. Tes diberikan untuk mengetahui tingkat penguasaan siswa terhadap materi pembelajaran, sedangkan penilaian kinerja digunakan untuk mengetahui kemampuan siswa dalam melakukan kinerja ilmiah dalam pembelajaran IPA. Hasil penilaian pembelajaran yang dilakukan guru pada kompetensi dasar "Menganalisis data percobaan gerak lurus beraturan" di kelas VII, "Mendeskripsikan alat-alat optik dan penerapannya dalam kehidupan seharihari" di kelas VIII dan " Medan magnet di sekitar arus listrik" di kelas IX SMPN Negeri 4 Singkawang diperoleh data seperti yang tersaji dalam tabel 1 .

Hasil belajar yang diperoleh siswa pada Tabel 1 di atas terdiri atas dua aspek, nilai praktik merupakan gambaran kemampuan siswa melakukan kinerja ilmiah yang diperoleh melalui penilaian kinerja ketika melakukan praktik dengan menggunakan media Kit, sedangkan nilai teori menggambarkan tingkat penguasaan siswa terhadap materi pembelajaran pada kompetensi dasar yang diperoleh melalui tes pada akhir kegiatan pembelajaran. Hasil belajar yang dicapai siswa kemudian dibandingkan dengan kriteria ketuntasan minimal (KKM) yang ditentukan.
Jurnal Ilmu Pendidikan Fisika

Volum 1 Nomor 1 Maret 2016. Halaman 16-22 p-ISSN: 2477-5959 e-ISSN: 2477-8451

TABEL 1

HASIL PENILAIAN PEMBELAJARAN IPA MELALUI PEMANFAATAN MEDIA KIT DI SMP NEGERI 4 KOTA SINGKAWANG

\begin{tabular}{lccccccc}
\hline & & \multicolumn{3}{c}{ Nilai Praktik } & \multicolumn{3}{c}{ Nilai Teori } \\
\cline { 3 - 7 } No & Kelas & $\begin{array}{c}\text { Ter- } \\
\text { tingi }\end{array}$ & $\begin{array}{c}\text { Te- } \\
\text { rendah }\end{array}$ & $\begin{array}{c}\text { Rata } \\
\text {-rata }\end{array}$ & $\begin{array}{c}\text { Ter- } \\
\text { tingi }\end{array}$ & $\begin{array}{c}\text { Te- } \\
\text { rendah }\end{array}$ & $\begin{array}{c}\text { Rata } \\
\text {-rata }\end{array}$ \\
\hline 1 & VII A & 87 & 60 & 77 & 100 & 50 & 77 \\
2 & VII B & 90 & 60 & 75 & 86 & 56 & 73 \\
3 & VII C & 89 & 60 & 69 & 84 & 60 & 78 \\
4 & VII D & 92 & 60 & 72 & 100 & 56 & 74 \\
5 & VII E & 91 & 58 & 74 & 88 & 60 & 85 \\
6 & VII F & 95 & 54 & 70 & 100 & 48 & 72 \\
7 & VIII A & 75 & 70 & 73 & 76 & 65 & 76 \\
8 & VIII B & 75 & 70 & 74 & 90 & 65 & 70 \\
9 & VIII C & 75 & 70 & 71 & 70 & 65 & 68 \\
10 & VIII D & 75 & 70 & 72 & 75 & 65 & 65 \\
11 & VIII E & 75 & 70 & 75 & 78 & 65 & 68 \\
12 & IX A & 87 & 55 & 79 & 90 & 60 & 75 \\
13 & IX B & 80 & 70 & 75 & 90 & 70 & 81 \\
14 & IX C & 80 & 70 & 74 & 96 & 46 & 76 \\
15 & IX D & 80 & 70 & 74 & 96 & 32 & 63 \\
16 & IX E & 85 & 70 & 75 & 100 & 42 & 73 \\
\hline
\end{tabular}

Kriteria ketuntasan mininal yang ditentukan pada mata pelajaran IPA di Kelas VIII SMP Negeri 4 Singkawang adalah 65. Dengan demikian berdasarkan hasil penilaian pembelajaran yang dilakukan dalam pembelajaran menunjukkan hasil yang melampau KKM. Hal ini dapat diartikan bahwa siswa mencapai ketuntasan belajar sesuai kriteria Ketuntasan yang ditentukan.

Hasil belajar yang dicapai siswa dengan pemanfaatan media Kit terbukti dapat meningkatkan kemampuan penguasaan materi pembelajaran serta meningkatkan kemampuan kinerja ilmiah siswa terutama dalam melakukan percobaan, melakukan pengamatan, pengambilan keputusan dan melaporkan hasil percobaan. Sesuai hasil observasi, wawancara dengan guru dan siswa diperoleh data bahwa dalam pelaksanaan pemanfaatan media Kit dalam pembelajaran, guru menunjukkan kemampuannya mengoperasikan media Kit, melibatkan siswa, memberikan bimbingan kepada siswa dan memperhatikan keselamatan dalam pemanfaatan media Kit selama pembelajaran.

Pembelajaran IPA di SMP diarahkan untuk meningkatkan penguasaan siswa mengenai diri dan lingkungan sekitarnya sehingga mampu memecahkan masalah yang dihadapi dalam kehidupan sehari-hari terutama berkaitan dengan lingkungan alam sekitar. Pembelajaran IPA di SMP juga mengembangkan kemampuan kinerja ilmiah 


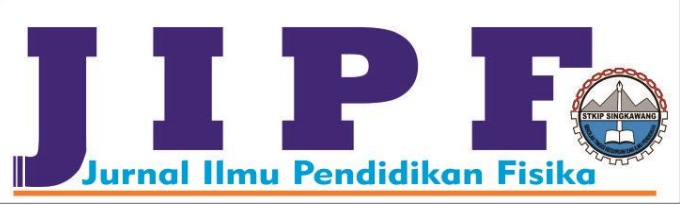

siswa melalui penerapan penerapan keterampilan proses diantaranya kemampuan melakukan observasi, percobaan, penelitian/memprediksi, dan mengambil keputusan.

Pemanfaatan media Kit menjadi salah satu alternatif untuk meningkatkan efektivitas pembelajaran, aktivitas belajar serta mortivasi belajar siswa dalam pembelajaran IPA. Media Kit dapat meningkatkan kegairahan belajar siswa, memungkinkan interaksi lebih langsung antara siswa dengan lingkungan dan kenyataan, serta memungkinkan siswa belajar sesuai dengan kemampuan dan minatnya. Pembelajaran yang efektif memungkinkan siswa memperoleh pengalaman yang sesuai dengan kenyataan kehidupan sehari-hari, sehingga pengalaman yang diperoleh melalui pemanfaatan media Kit dalam pembelajaran IPA bermakna bagi kehidupan siswa [8]. Pengalaman yang diperoleh melalui penerapan keterampilan proses dalam pembelajaran yang dimulai dengan melakukan pengamatan, mengidentifikasi hasil pengamatan, melakukan demonstrasi atau percobaan, memprediksi kejadian dan mengambil keputusan dari alternatif yang muncul memungkinkan siswa terlatih untuk percaya diri, mandiri dan mampu menentukan pilihan.

Temuan penelitian mengenai pemanfaatan media Kit dalam pembelajaran IPA di SMP Negeri 4 Kota Singkawang meliputi kegiatan pemilihan media Kit, persiapan penggunaan Kit, pelaksanaan dalam pembelajaran, penyimpanan dan perawatan, serta dampak terhadap kegiatan pembelajaran. Sebelum pemanfaatan media Kit dalam pembelajaran perlu dilakukan pemilihan media Kit sesuai dengan tujuan pembelajaran yang akan dicapai atau dengan kata lain kompetensi yang diharapkan dikuasai siswa. Aspek-aspek yang dipertimbangkan guru IPA SMP Negeri 4 Kota Singkawang dalam pemilihan media Kit yang akan digunakan pada pembelajaran IPA meliputi: (1) materi pembelajaran yang akan dibahas, (2) ketersediaan media, (3) alokasi waktu pembelajaran yang disediakan, dan terakhir (4) keselamatan dan kenyamanan siswa.

Secara umum pemilihan media termasuk media Kit harus mempertimbangkan tujuan yang akan dicapai atau kompetensi apa yang diharapkan dimiliki siswa melalui pembelajaran. Selain itu, harus memperhatikan pula aspek karakteristik siswa dan kemampuan guru dalam mengoperasikan. Karakteristik siswa harus mendapat perhatian saat melakukan pemilihan media Kit terutama jumlah siswa karena berkaitan dengan jumlah media yang dibutuhkan. Demikian pula aspek kemampuan guru, sebab ketika mengenalkan media, cara kerja, membimbing dan mengarahkan siswa memerlukan keterampilan guru dalam mengoperasikan media Kit yang digunakan.

Media Kit terdiri dari sejumlah komponen yang merupakan suatu sistem memerlukan persiapan yang cukup sebelum digunakan dalam kegiatan pembelajaran. Pemanfaatan media Kit dalam pembelajaran IPA yang dilaksanakan guru di SMP Negeri 4 Kota Singkawang diperoleh temuan tahapan pemanfaatan media Kit yang terdiri dari tahap persiapan, pelaksanaan, dan penyimpanan. Tahap persiapan dilakukan kegiatan pengecekan kelengkapan setiap komponen Kit yang akan digunakan, melakukan ujicoba untuk mengetahui kondisi setiap komponen dan berfungsi tidaknya Kit yang akan digunakan. Kegiatan persiapan dilakukan guru sebelum pelaksanaan pembelajaran, karena itu perlu dipertimbangkan waktu ujicoba dengan kegiatan pembelajaran yang akan menggunakan media Kit. Hal itu untuk mengantisipasi pengambilan alternatif lain jika media Kit yang akan digunakan tidak lengkap, atau terdapat komponen yang tidak berfungsi. Persiapan ini menjadi penting agar pemanfaatan media Kit dalam pembelajaran dapat terlaksana dengan lancar dan dapat mendorong terwujudnya pembelajaran yang efektif, menyenangkan.

\section{KESIMPULAN}

Berdasarkan deskripsi hasil penelitian,analisis, temuan dan pembahasan hasil penelitian, secara umum dapat disimpulkan bahwa pemanfaatan media Kit telah dilaksanakan guru dalam pembelajaran IPA di SMP Negeri 4 Kota Singkawang. Pemanfaatan media Kit IPA di SMP Negeri 4 Singkawang dapat meningkatkan aktivitas belajar siswa, minat siswa belajar terhadap pembelajaran IPA, menciptakan suasana belajar yang mengasikkan dan menyenangkan, serta mengembangkan kemampuan siswa bekerjasama dan berpartisipasi dalam kegiatan kelompok. Hasil 


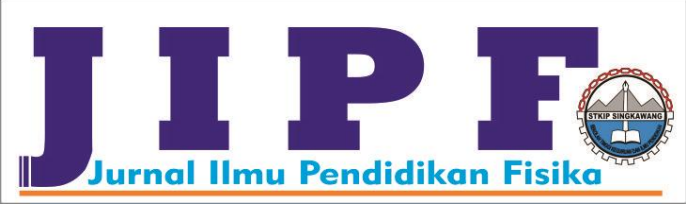

belajar yang dicapai siswa dengan pemanfaatan media Kit IPA di SMP Negeri 4 Singkawang menunjukkan hasil yang memuaskan, terbukti dengan tingkat pencapaian hasil belajar yang melampaui kriteria ketuntasan minimal, meliputi kemampuan teoretis dan keterampilan kinerja ilmiah siswa.

Berdasarkan kesimpulan dan implikasi hasil penelitian pemanfaatan media Kit IPA, disarankan: (a) Meningkatkan frekwensi pemanfaatan media Kit dalam pembelajaran IPA baik pada kajian fisika, biologi, maupun kimia, serta mengembangkan kreativitas dan inovasi pembelajaran melalui pemanfaatan media Kit; (b) Proses pemilihan media Kit yang akan digunakan dalam pembelajaran hendaknya tetap mempertimbangkan tujuan atau kompetensi yang diharapkan, karakteristik siswa dan kemampuan guru menggunakan media Kit; (c) Persiapan pemanfaatan media Kit hendaknya dilakukan secara menyeluruh dari pengecekan ketersediaan multimedia, kelengkapan komponen dan pengujian media Kit; dan (d) Membuat media sederhana sebagai alternatif pengganti media Kit yang tidak tersedia atau kurang lengkap dengan memanfaatkan barang-barang bekas.
Jurnal Ilmu Pendidikan Fisika

Volum 1 Nomor 1 Maret 2016. Halaman 16-22 p-ISSN: 2477-5959 e-ISSN: 2477-8451

\section{UCAPAN TERIMAKASIH}

Peneliti mengucapkan terima kasih kepada Kepala Sekolah SMP serta guru IPA Negeri 04 Singkawang. Tidak lupa juga peneliti mengucapkan kepada STKIP Singkawang yang telah menerbitkan jurnal ilmiah penelitian ini.

\section{DAFTAR PUSTAKA}

[1] Undang-Undang No. 20 Tahun 2003 tentang "Sistem Pendidikan Nasional", Surabaya: Karina, 2003.

[2] R.W. Dahar, "Teori-teori Belajar", Jakarta : Erlangga, 1996.

[3] Arsyad, Azhar, "Media Pembelajaran", Jakarta : Raja Grafindo Persada, 2010.

[4] P. Bundu, "Penilaian Keterampilan Proses dan Sikap Ilmiah dalam Pembelajaran Sains", Jakarta : Depdiknas, 2006.

[5] Sanjaya, Wina, "Strategi Pembelajaran Berorientasi Standar Proses Pendidikan", Jakarta ; Kencana Prenada Media, 2010.

[6] Ary, Donald ,Lucy Cheser Jacobs, Asghar Razavieh, "Pengantar Penelitian dalam Pendidikan Terjemahan Arief Furchan", Yogyakarta : Pustaka Pelajar, 2004.

[7] Sugiyono, "Metode Penelitian Pendidikan Pendekatan Kualitatif, Kuantitatif dan R\&D", Bandung : Alfabeta, 2007.

[8] Sukmadinata, Nana Syaodih, "Metode Penelitian Pendidikan", Bandung : Remaja Rosdakarya, 2005.

[9] Miles, B. Matthew Dan Huberman, A. Michael, "Analisis Data Kualitatif Terjemahan Tjetjep Rohendi Rohidi", Jakarta : Penerbit Universitas Indonesia, 1992. 